\title{
Satifaction As Intervening For The Antecedents Of Intention To Revisit: Marine Tourism Context In East Java
}

\author{
Achmad Yanu Alif Fianto \\ Faculty of Economy and Business, Universitas Dinamika, Surabaya
}

\begin{abstract}
The purpose of this study was to identify the effect of brand experience and service quality on intention to revisit with satisfaction as a mediating variable in the marine tourism in Indonesia. A total of 241 worthwhile questionaires were collected to be used to examine the structural model and the measurement using PLS path modelling analysis. This research was conducted in several coastal tourism objects in East Java, which were emphasized on the north coast of East Java. This study found that service quality has a significant effect on intention to revisit. This study also revealed that at the same time brand experience also had a significant influence on intention to revisit. In addition, this study also revealed that visitor satisfaction was significantly also able to mediate the relationship between service quality with intention to revisit while also having a mediating function of the relationship between brand experience with intention to revisit. This can be interpreted that the coastal tour manager should focus on improving service quality and developing visitor experience in order to enhance tourists' emotional attachments to the coastal tourism area to shove repeat visits among visitors. This research has contributed to an increase in understanding of the effect of service quality and brand experience on intention to revisit by adding satisfaction variables that serve as mediation. In addition, the findings of this study can be very beneficial for the development of coastal tourism in East Java, Indonesia.
\end{abstract}

Keywords: Brand Experience, Service Quality, Satisfaction, Intention to Revisit, East Java

\section{Introduction}

Sea shore areas and marine resources in Jawa Timur Province are developing in all regards rapidly. Also, it is arranged in a key situation with the objective that it has financial points of interest as outside exchange from charges. In any case, there is moreover a negative impact on the waters, especially the region and the se a coast. This is if no movement will happen continually, which is a direct result of the nonattendance of system care of nature, for instance, calculating, fish developing, and the movement business which depends solely on fiscal points of 
interest. Regardless, a segment of these things can carry flourishing to ocean side systems at whatever point done suitably.

Branding is difficult yet serviceable for brandings when it is associated in an indispensable manner, using market information (Keller, 1993). To make branding increasingly strong, an intentional system is required (Hasiri and Afghanpour, 2016; Lam et al., 2015; Fazal et al., 2014; Nyadazayo and Khajehzadeh, 2016). In any case, wide research is required in the midst of the movement of making a brand point thought, with a dominant part rule approach to manage hear the voices everything being equivalent, including nearby individuals without a direct fiscal excitement for the movement business (Ofori et al., 2018; Irfan et al., 2016; Quach et al., 2016; Hasiri and Afghanpour, 2016; Ewur and Ali, 2016). The prescribed structure can be valuable for specialists in surrounding their branding practices for any element of branding things (Rezaei, 2015; Tang, 2014; O’Mahony et al., 2013; Arshad et al., 2016). Occupants are be pondered twice, both from free market movement side perspectives (Ewur and Ali, 2016; Adam et al., 2018). This is purposely proposed in view of the essential occupation of inhabitants as the two providers and clients of a spot. Evaluation of their perspective is of most extraordinary centrality in working up a productive and key brand.

As service expenence assumes a huge job in the achievement of firms working in the cordiality business and purchaser experience assumes a key job in understanding shopper conduct in showcasing; thus, an upgraded comprehension of the experiential wonders in accommodation service is especially significant, and will empower more grounded industry execution (Deng et al., 2013; Arshad et al., 2016; Rezaei et al., 2017; Hasiri and Afghanpour, 2016). Notwithstanding the significance of the experiential perspective, the travel industry and friendliness quality additionally adds to the long haul practical improvement of a world economy and, in spite of the fact that the unmistakable quality of service quality has been featured in the travel industry and accommodation writing, background related research remains underrepresented (Irfan et al., 2016; Hasiri and Afghanpour, 2016; Hassanli et al., 2016; Aissa et al., 2016). Moreover, while ebb and flow writing usually explores the frame of mind, satisfaction, and conduct of a 
traveler's goals, constrained research has analyzed an accomplished visitor's genuine spending conduct in a rising the travel industry condition (Keshavarz and Jamshidi, 2018; Nyadazayo and Khajehzadeh, 2016; Ofori et al., 2018; Richter et al., 2015).

One factor that is considered have noteworthy effect to the intention to revisit is service quality. Quality is considered as the ability to meet the total customers communicated needs and requirements (buyer perceptions and wants) toward organization's offering (Parasuraman et al., 1988; Richter et al., 2015; Tang, 2014; Khodadadi, 2016; Keshavarz and Jamshidi, 2018). It has been represented that positive buyer perceptions and suppositions with respect to the service quality prompts satisfaction ultimately yield positive direct points since service quality generally relies upon complete customer decisions of the prevalence of the service and along these lines arranges buyer wants for the services (Parasuraman et al., 1988; Martinez and Rodriquez, 2013; Lee and Kim, 2018; Ewur and Ali, 2016; Theodorakis et al., 2013). As per parasuraman et al. (1998), quality is the finished hole between customer wants and impression of organization's presentation; along these lines, the greater the positive hole brings about the more essential the service quality. As of now, it is broadly fathomed that service quality and satisfaction are connected, yet they are moreover obvious creates and they are generally seen as signs of purchasers dependability. Administration quality and purchasers (guests) satisfaction furthermore have little simultaneousness on the possibility of their relationshiop. It was in like manner assumed that guest relentlessness was outstandingly related with the satisfaction of the travel industry service qualities.

The other factor which is seen as the forerunner of intention to revisit or buyer devotion is brand experience (Deng et al., 2013; Ekinci et al., 2008; Irfan et al., 2016). Brand system is seen as one of the top issues in the travel industry business and is transforming into a central segment in the travel industry improvement (Jani and Han, 2014; Howat and Assaker, 2013; Lee and Kim, 2018). This is on the grounds that that relationship marketing prompts brand steadfastness that binds the client to the merchant, in any occasion, when such trustworthiness is apparently contrary to the buyer's close to home premium (Arshad et al., 2016; Nam et al., 
2011; Rezaei, 2015; Theodorakis et al., 2013; Ofori et al., 2018). Relationship advancing correspondence (Quach et al., 2016). Buyers dynamically buy brands for experiential bit of leeway, as opposed to helpful favorable position . Along these lines, customer relationship management is one of the down to earth decisions to amass firm brand among target customers. The higher the brand experience an individual has, the higher the enthusiastic duty the individual will have towards that brand. In the travel industry, brand determinedly impacts a clients come back to objective as brand has a parallel or dispute impact on buyers. Brakus et al. (2009) anticipated that brand experience insistently impacts buyers satisfaction and reliability toward general thing types.

In the contrary side, numerous examines found that satisfaction is a key factor that decide the steadfastness or in term of the travel industry, intention to revisit (Martinez and Rodriquez, 2013; Lam et al., 2015; Keshavarz and Jamshidi, 2018; Quach et al., 2016; O'Mahony et al., 2013). Shopper satisfaction is the result of a product or services surprassing the clients' or guests' wants and from guests' extraordinary experiences (Saleem et al., 2017; Tanford, 2013; Lee and Kim, 2018). Fulfillment is the client's inclination that usage gives results against a standard of pleasure versus dissatisfaction (Lee and Kim, 2018). Buyer satisfaction contains both scholarly strategy, loaded with feeling process, mental and physiological effects (Keshavarz and Jamshidi, 2018; Hasiri and Afghanpour, 2016). In addition, customer loyalty is ordinarily described as a client's objective or real spending led to more than one to purchase certain products or services (Adam et al., 2018; Rezaei et al., 2017; Rezaei, 2015; Ofori et al., 2018). Purchaser loyalty may not commonly provoke relentlessness; regardless of whether, past research interpret that satisfied customers are less worth sensitive and intend to be unwavering, regardless, the association among satisfaction and intention to revisit is a littler sum clearness (Theodorakis et al., 2013). Guests' faithfulness identifies with guests' sure miens toward a thing, together with their mean to repurchase the services a great part of the time (Mohseni et al., 2016).

The motivation behind this research is to look at the effects of service quality, and brand experience on consumer loyalty, just as the intention to revisit of 
experienced tourists in Indonesia. All the more explicitly, we are taking a look at the accommodation business in Indonesia and how autonomous factors influence intention to revisit, straightforwardly and in a indirect way, through satisfaction. This research is sorted out in the accompanying areas. Initially, the hypothetical foundation of the research is talked about and theories are proposed likewise. The segment incorporates a clarification of key research develop connections. Also, the exploration technique and configuration are proposed to exactly test the hypothetical research system. Thirdly, the information investigation and results are displayed. In conclusion, a dialog of the discoveries is displayed alongside useful results and constrictiona.

The reason for this research is to look further at the effects service quality and brand experience on consumer loyalty, just as the enthusiasm to return to of experienced travellers in indonesia. This research is sorted out in the accompanying areas. The hypothetical foundation of the research is talked about and speculations are proposed in like manner. The area incorporates a clarification of key research construct connections. Besides, the exploration philosophy and configuration are proposed to observationally test the hypothetical research system. The information of this research and results are displayed. Finally, discussions around the findings and discoveries is exhibited alongside commonsense results and obstacles.

\section{Literature Review and Hypotheses}

This research proposes an integrative hypothetical system based upon SERVQUAL, consumer loyalty, consumer behavior and brand experience. Hypothesis based research has propelled our comprehension of service quality construct in the pleasantness and the travel industry setting, nevertheless there is as yet a need to refine the conjectures and procedures with the goal that the prescient intensity of existing models can be upgraded (Arshad et al., 2016; Bilgihan et al., 2016; Ferns and Wall, 2012). Truth be told, the hypothetical worldview in the travel industry and accommodation is still in its underlying phase of improvement (Christopher et al., 2013; Ewur and Ali, 2016; Irfan et al., 2016; Lee, 2015; Hasiri and Afghanpour, 2016). 


\section{Service Quality}

According to Parasuraman et al. (1998), quality is the complete gap between consumer desires and impression of company's performance; in this way, the bigger the positive gap results in the more noteworthy the service quality. Quality is considered as the capacity to meet the complete shoppers expressed needs and prerequisites (purchaser observations and desires) toward company's offering (Teng, 2011). Even if, quality in the travel industry related service is tied in with appropriate consumer recognitions and desires, there is an absence of consensus about the service quality construct, and it stays a slippery idea (Teng, 2011; Shi et $a l ., 2014)$. It has been accounted for that positive consumer observations and assumptions regarding the service quality prompts fulfillment lastly yield positive conduct aims since service quality for the most part depends on complete consumer choices of the predominance of the service and in this way coordinates purchaser desires for the services (Manhas and Tukamushaba, 2015). Consequently, as a key precursor to consumer loyalty, service quality assumes a significant job in the money related feasibility of a company (Keshavarz and Jamshidi, 2018).

Multidimensional conceptualization of service quality recognizes the significant components impacting loyalty (Jin et al., 2015). In spite of the fact that service quality is arranged in layered dimensions, the result of research is uncertain and there has been little concurrence on the nonexclusive and explicit service quality measurements (Kandampully et al., 2014). In order to support the service company to recognize their qualities and shortcomings, the SERVQUAL model, a symptomatic device comprising of 22 things, evaluates the five proposed key support factors, examined as a consumer based model. The issue of estimating Service Quality has gotten expanded consideration, as of late, in the travel industry and diversion writing (Parasuraman et al., 1988; Peterson, 1995). Service quality is a complex model comprising of three sub-measurements: Interaction Quality, Service Environment Quality, and Outcome quality (Parasuraman et al., 1988). Regardless of a few quality and analysis, SERVQUAL as a basic instrument which gives successful proof on an organizations' service quality. The SERVQUAL five measurements incorporate Tangibles, Assurance, Reliability, Empathy, and 
Responsiveness.

The reliability is viewed as the ability to play out the guaranteed administration constantly and precisely (Parasuraman et al., 1988; Amin, 2016; Bilgihan et al., 2016). Assurance is characterized as knowledge and affability of workers and their capacity to rouse trust and certainty (Parasuraman et al., 1988; Kandampully et al., 2014). Responsiveness is characterized as willingness to support consumers and give brief assistance and empathy is interpreted as caring, individualized consideration the firm gives its consumers (Parasuraman et al., 1988; Keshavarz and Jamshidi, 2018). While tangibility is affirmed as physical offices, gear and presence of staff (Parasuraman et al., 1988; Manhas and Tukamushaba, 2015).

Currently, it is widely comprehended that service quality and fulfillment are related, yet they are likewise unmistakable develops and they are usually viewed as indications of consumers faithfulness (Peterson, 1995; Rahman, 2014; Rezaei, 2015). Top notch company's all out services can held consumer loyalty which includes a general impression of the prevalence or inadequacy of the services, so the service quality and fulfillment upgrade consumers' social expectations and care (O’Mahony et al.,, 2013; Ofori et al., 2018).

Parasuraman et al., (1988) stated that service quality is decidedly identified with fulfillment, and fulfillment is emphatically identified with confidence. Service quality and consumers (visitors) satisfaction additionally have little concurrence on the idea of their relationship (O’Mahony et al., 2013; Lewis et al., 2013). It was likewise presumed that visitor steadfastness was exceptionally related with the fulfillment of tourism service characteristics (Manhas and Tukamushaba, 2015). Service quality impacts travelers' future goal determination aims with more significant levels of service quality prompting more prominent expectations to return to, while saying service quality has an immediate beneficial outcome on their fulfillment and is a predecessor of fulfillment (Quach et al., 2016; Khodadadi, 2016; Lee and Kim, 2018). Among variables prompting the accomplishment of accomodations, providing food, and the travel industry ventures, offering great help is generally recognized as significant (Rezaei, 2015). Therefore a hypothesis can be 
arranged as follows:

H1.Service quality positively has significant impact on intention to revisit. H2.Service quality positively has significant impact on satisfaction.

\section{Brand Experience}

As the significance of the hospitality business is ceaselessly developing, making a genuine cordiality experience for consumers can expand consumer loyalty and business execution (Deng et al., 2013; Chang et al., 2010; Aissa et al., 2016; Hsu et al., 2011). Brand strategy is viewed as one of the top issues in the tourism business and is turning into a fundamental component in tourism improvement (Ekinci et al., 2008; Brakus et al., 2009; Amin, 2016; Berezan et al., 2013; Adam et al., 2018). Brands might be related, in the nerves of buyers, with execution, in regard to these difficult-to-watch item qualities (Fazal et al., 2014; George et al., 2016; Jin et al., 2015; Keller, 1993; Keshavarz and Jamshidi, 2018).

Brand Experiences (BRANDEX) impact positive results, for example, return to expectation and it is broadly perceived in buyer conduct as a system in brand box techniques (O’Mahony et al.,, 2013; Lee and Kim, 2018; Martinez and Rodriquez, 2013; Kandampully et al., 2014). As a vital device, the way toward building a brand begins from separating their products or services from those of its rivals while clients experience a brand through different brand contact focuses (Khodadadi, 2016; Lam et al., 2015; Jani and Han, 2014; Iglesias et al., 2011). Brand experience is unmistakable from brand associations and brand image, which is conceptualized as abstract, inner purchaser reactions (sensations, emotions, and perceptions), and social reactions evoked by Brand-Relation (Manhas and Tukamushaba, 2015; Lewis et al., 2013; Lee et al., 2015; Ofori et al., 2017). The BRANDEX have three measurements called Behavioral Brand Experience, Sensory Brand Experience, Affective Brand Experience and Intellectual Brand Experience (Nam et al., 2011; Magasi, 2016; Nyadazayo and Khajehzadeh, 2016; Mohseni et al., 2016).

Relationship marketing prompts brand loyalty that ties the customer to the seller, in any event, once such dependability is by all accounts in opposition to the consumer's personal interest. relationship promoting correspondence (Howat and Assaker, 2013; Hassanli et al., 2016; Teng, 2011; Ronkko and Evermann, 2013). 
While for sellers, the intensity of relationship marketing is that brand loyalty can mean store loyalty and doubtlessly it would brings about increment brand loyalty or brand equity, an unmistakable qualification between relationship marketing exercises and promoting exercises exist (Rezaei, 2015; Peterson, 1995; Oh and Hsu, 2014). Social Brand Experience is characterized as various sorts of encounters identified with the physical body whether they are identified with entertainment, nightlife, or even food (Shi et al., 2014). While Sensory Brand Experience is situated as when guests experience tangible encounters, they sense what happens outside the body and a large portion of their affiliations will be identified with the visual idea of encounters (Richter et al., 2015). At that point, Affective Brand Experience is decoded as full of feeling experiences can bring about feelings that are mellow (e.g., states of mind) or exceptional (e.g., emotions and suppositions). In conclusion, Intellectual Brand Experience is known as Intellectual encounters happen when the brand stimulates a visitors' interest (Tang, 2014; Tanford, 2013).

Consumers progressively purchase brands for experiential advantage, rather than useful advantage (Saleem et al., 2017; Rahman, 2014; Quach et al., 2016). Travelers assess accommodation execution, not founded on hotel capacities, yet dependent on hotel brand quality (Richter et al., 2015; Han et al., 2011). In this way, customer relationship management is one of the practical choices to assemble firm brand among target clients. Besides, individuals' movement advantages, selection, and dependability are fundamental prerequisites in brand building; consequently, changes in these components can fill in as indicator factors for understanding the upgrade of brand (Hsu et al., 2011; Bilgihan et al., 2016; Chang et al., 2010). Visitor fulfillment has filled in as a proportion of operational accomplishment for marking methodologies and achieved positive encounters through hotel brand experiences (Manhas and Tukamushaba, 2015; Lee and Kim, 2018; Lee et al., 2015). Hotel brands contributes an incentive to guarantee that a uniform degree of value exist (Mohseni et al., 2016; Nyadazayo and Khajehzadeh, 2016; Keshavarz and Jamshidi, 2018).

The higher the brand experience an individual has, the higher the emotional responsibility the person will have towards that brand (Magasi, 2016; Lee, 2015). 
In the tourism industry, brand decidedly influences a customers return to goal as brand has a parallel or controvert effect on consumers (Richter et al., 2015; Saleem et al., 2017). Brakus et al. (2009) predicted that brand experience emphatically influences consumers fulfillment and loyalty toward general item types. An elevated level of brand value expands purchaser fulfillment, repurchasing purpose, and level of steadfastness (Ronkko and Evermann, 2013). Iglesias et al. (2011) wondered that accommodation image positively affects generally speaking loyalty. Past research suggests that a fruitful brand technique help more noteworthy shopper dedication since consumers' goals to come back to a specific accommodation brand are normally connected with faithfulness. Thus, the hypothesis can be formulated as follows:

H3. Brand experience positively has significant impact on intention to revisit.

H4. Brand experience positively has significant impact on satisfaction.

\section{Customer Satisfaction and Intention to Revisit}

Consumer satisfaction contains both intellectual procedure, full of feeling process, mental and physiological impacts (Berezan et al., 2013). Consumer satisfaction is the consequence of a product or services surprassing the customers' or visitors' desires and from visitors' great encounters (Arshad et al., 2016). Satisfaction is the customer's feeling that utilization gives results against a standard of delight versus disappointment (Deng et al., 2013).

Moreover, customer loyalty is typically characterized as a customer's goal or actual spending conducted to more than one to buy certain products or services (Ekinci et al., 2008). Oliver (1997 and 1999) proposed a structure of buyer reliability involving four particular, successive stages including cognitive loyalty, affective loyalty, conative loyalty and action loyalty. Conative reliability is viewed as Loyalty to a goal that comprises the advancement of social aims described by a more profound degree of duty (Jani and Han, 2014). Cognitive loyalty is characterized as main considerations on various important information such as, for example, value, highlights and so on which alludes to the presence of convictions that a brand is desirable over others (Howat and Assaker, 2013; Irfan et al., 2016). While Affective Loyalty translated as Loyalty to an enjoying that reflects an ideal 
disposition or loving dependent on fulfilled utilization (Lee, 2015; Lee and Kim, 2018).

Consumer loyalty may not generally prompt steadfastness; even if, past investigation infer that fulfilled clients are less value delicate and mean to be faithful, in any case, the connection among Satisfaction and Intention to Revisit is a smaller amount clarity (Shi et al., 2014). Visitors' loyalty relates to visitors' positive dispositions toward an item, together with their aim to repurchase the services much of the time (Peterson, 1995; Martinez and Rodriquez, 2013). Consumer loyalty impacts dedication, for example, rehash visits and decidedly impacts brand faithfulness as experimental outcomes propose that high brand value prompts progressively ideal fulfillment and purchasers in general conduct expectations (Manhas and Tukamushaba, 2015; Lee, 2015; Keshavarz and Jamshidi, 2018). Consumer loyalty may impact brand through one immediate and one backhanded channel. Showcasing specialists recognize that administration quality has both immediate and roundabout impacts on consumer commitment. An uplifting behavior toward a specific item or brand is probably going to lead clients to constant support, and improved recurrence of support (Teng, 2011; Han et al., 2011; Deng et al., 2013). Therefore the following hypothesis can be arranged.

H5: Satisfaction positively influences intention to revisit.

\section{Research Framework}

Various kinds of research need to be considered by marketing managers are required to support the factors that influence consumer loyalty or in the context of this research is the intention to review. Therefore, this research was conducted as an effort to develop antecedents of consumer loyalty or intention to revisit, namely service quality and brand experience while helping mediation of satisfaction in service quality relationships and brand experience with intention to revisit. The research model proposed in this study uses validation using SEM (Structural Equation Model). Explanation of the hypothesis formulation already exists in the hypothesis development section and is discussed in the measurement model in Figure1. The model is arranged through 5 research hypotheses. An explanation of 
the relationships between variables is formulated in $\mathrm{H} 1$ - $\mathrm{H} 5$.

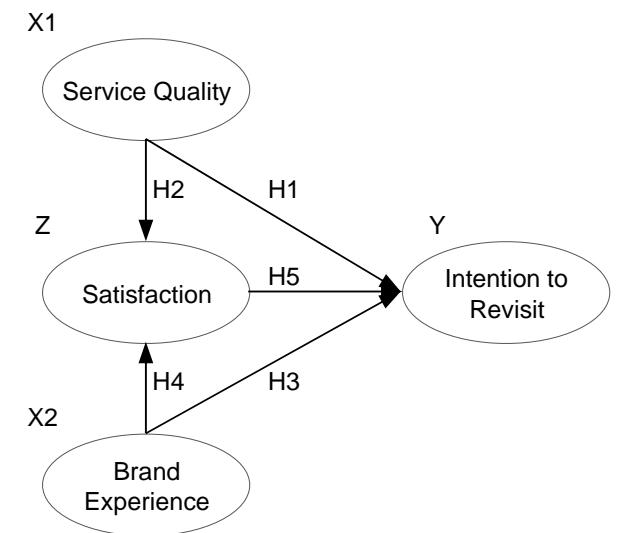

Figure 1. Conceptual Framework

\section{RESEARCH METHODS}

To experimentally measure the proposed research model, a quantitative strategy was encompassed. To quantify research constructs, a questionnaire was planned in two principle areas; the primary segment catches data in regards to the profile of respondents which is described in descriptive statistics (Table 1), and the subsequent segment was intended to catch data in regards to the traveler's evaluation of their involvement with the Marine Tourism Attractions. The survey in the subsequent area was received from past investigations.

Before primary information gathering, to survey the legitimacy and solid quality of market research, a pre-test and pilot test were directed. For the pre-test, 30 samples were gathered among target population at one Marine Toursim Attraction in East Java, Indonesia. The poll was changed by respondents' input to ensure that respondents would comprehend the inquiries and that the review was anything but difficult to pursue. The information was divided regarding inward consistent quality utilizing Cronbach's Alpha as a pointer. Additionally, a pilot test was led among five Marine Tourism Attractions visitors before genuine dispersion of questionnaires. The information was broke down utilizing Partial Least Square (PLS) Path Modeling Approach and since the outcomes were pleasant, we continued with the principle information accumulation techniques (The informational collection for the pre-test and pilot-test were excluded in the fundamental information examination). 
Since PLS, structural equation modelling technique (PLS-SEM) is less affected by small sample sizes, the rule of thumb was performed in this study to set an appropriate sample size. Accordingly, at least 10 times the number of items, of the most complex construct, was considered to determine an adequate sample size. A total of 250 questionnaires were distributed, of which 241 questionnaires were collected ( $84 \%$ response rate), to empirically assess the measurement and structural model using partial least square (PLS) path modelling approach, a structural equation modelling (SEM) technique. Therefore, 220 responses were determined as the minimum requirement to conduct statistical analysis using PLS-SEM.

In the differing view, three stages were taken to guarantee that the nonreactions were not an issue in this research. Initially, wave examination was performed and the informational collection was separated into two sets and the outcomes infer that there is no huge contrasts between those two arrangements of information. At long last, examination of known statistic attributes, for example, sex, age, ethnicity and pay, length of remain (in days), motivation behind visits and correlation of main construct of the research, for example, Brand Experience, Service Quality, and Satisfaction, indicated no noteworthy contrasts between crowds, utilizing t-Test examination. The outcomes suggest that the non-response predisposition isn't a burden in this investigation.

\section{PLS-SEM}

The measures were viewed as composites and the PLS-SEM technique depicted above was utilized to break down the information gathered for this research. According to Hair et al. (2011) some scholarly contentions against PLSSEM depend on the PLS thinking utilized in the past to legitimize PLS-SEM contemplates (small sample size, formative indicators and so on). Notwithstanding, the contentions utilized in earlier PLS-SEM studies were off base, and ongoing reenactment studies exhibit that PLS-SEM is a seamless device to assess composites (Peterson, 1995). PLS-SEM was utilized to play out a logical and a further prescient research.

Following Hair et al. (2011) suggestions, the connections between the various constructs and the indicators were broke down utilizing a composite procedure. For 
this situation, the Latent Variable is comprehended as a blend of the Indicators, and PLS-SEM is accordingly a profoundly suitable device for these measures. The explanatory analysis was partitioned into three phases. The first surveys the Model Fit for the by and large or worldwide model (the Estimated Model). The second assesses the estimation (Outer) model, distinguishing the connections between recognizable factors and the hypothetical ideas indicated. Different measures, for example, Cronbach's Alpha and Composite Reliability, can likewise be incorporated. Despite the fact that Reliability esteems as low as 0.7 show appropriate unwavering quality in the beginning times of research, higher estimations of 0.8 or 0.9 ought to be utilized in further developed research.

The Average Variance Extracted (AVE) fills in as a proportion of Unidimensionality and Convergent Validity. On the whole, performing SEM method for appraisal of Hypothesis and Construct estimations is advantage on the grounds that enable scientists to evaluate or change theories/models. Of two fundamental SEM systems, Maximum Likelihood (MLE) technique for a Covariance-Based SEM (CB-SEM) is favored when we mean to test a hypothesis and connections and spotlight is on estimation errors. The subsequent all around perceived SEM system is PLS-SEM which surveys both relationships among latent constructs and indicators. Critically, MLE required rigid investigation of hypothesis while PLS-SEM is adaptable in presenting research constructs. PLS-SEM is favored over MLE when we expect to expand existing auxiliary hypothesis. Despite reactions, PLS-SEM methodologies and its procedure in testing a perplexing model is advantage in light of the fact that the point of research is expectation precision. PLS is likewise proper for exploratory and corroborative examinations since it is a reasonable instruments in evaluation of intricate and huge associations with numerous builds connections and things. The PLS calculation enables every pointer to differ in the amount it adds to the composite score of the inactive variable. Along these lines, SmartPLS programming is utilized in this examination.

\section{RESULTS}

\section{Respondents Profiles and Characteristics}

Table 1 outlines the example trademark including sexual orientation, age, ethnicity, 
marital status, training, month to month pay and the respondents motivation behind travel just as their length of remain (in days). $95.4 \%$ of all out example were Indonesian and $4.6 \%$ were foreigner. A greater part of the respondents' motivation for traveling around was vacation (44\%), while 39\% went for business and relaxation and the rest is traveled distinctly for business purposes. Moreover, respondents had in any event 1 day experience (50.2\%) in the length of remain in days when they reacted to this research. Fewer encountered the accommodation 6 to 10 days, $39.8 \%$ experienced it for 2 to 5 days and $1.2 \%$ encountered the travel for more than 10 days.

Table 1. Respondents Profiles and Characteristics ( $\mathrm{N}=241)$

\begin{tabular}{|c|c|c|c|c|}
\hline$\#$ & Profile & Measurement & Occurance & Ratio (\%) \\
\hline \multirow[t]{2}{*}{1} & Gender & Male & 134 & 55.6 \\
\hline & & Female & 107 & 44.4 \\
\hline \multirow[t]{4}{*}{2} & Age & Below 22 & 84 & 34.9 \\
\hline & & 23 to 30 & 76 & 31.5 \\
\hline & & 31 to 40 & 49 & 20.3 \\
\hline & & Older than 40 & 32 & 13.3 \\
\hline \multirow[t]{2}{*}{3} & Ethnicity & Indonesian & 230 & 95.4 \\
\hline & & Foreigner & 11 & 4.6 \\
\hline \multirow[t]{3}{*}{4} & Marital Status & Single & 129 & 53.5 \\
\hline & & Married & 101 & 41.9 \\
\hline & & Not stated & 11 & 4.6 \\
\hline \multirow[t]{4}{*}{5} & Education & High School & 17 & 7.1 \\
\hline & & Diploma & 43 & 17.8 \\
\hline & & Undergraduate & 166 & 68.9 \\
\hline & & Graduate & 15 & 6.2 \\
\hline \multirow[t]{4}{*}{6} & Monthly income & Less than IDR 2.000 .000 & 9 & 3.7 \\
\hline & & IDR 2.000.000 - IDR 3.200 .000 & 95 & 39.4 \\
\hline & & IDR 3.200.001 - IDR 6.000 .000 & 106 & 44.0 \\
\hline & & More than IDR 6.000 .000 & 31 & 12.9 \\
\hline \multirow[t]{3}{*}{7} & Travel Purposes & Business & 41 & 17.0 \\
\hline & & Vacation & 106 & 44.0 \\
\hline & & Business and Vacation & 94 & 39.0 \\
\hline \multirow[t]{4}{*}{8} & Length of Visits & 1 day & 121 & 50.2 \\
\hline & & 2 to 5 days & 96 & 39.8 \\
\hline & & 6 to 10 days & 21 & 8.7 \\
\hline & & More than 10 days & 3 & 1.2 \\
\hline
\end{tabular}




\section{Measurement Model}

To be exactly and visibly survey quick estimations things, the investigation analyzed the external/factor loadings and Composite Reliability (CR). Moreover, as a marker of joined legitimacy, Average Variance Extractedand discriminant validity among constructs were evaluated. As appeared in Table 2, outer loadings for all items are well above least limit of 0.60, and all builds have significant levels of inner consistency or dependability, as appeared by the above CR values. The AVE values are well over the base required degree of 0.50 , displaying concurrent legitimacy for all exploration builds.

Table 2. Construct Validity

\begin{tabular}{|c|c|c|c|c|c|c|}
\hline $\begin{array}{l}\text { Second } \\
\text { order } \\
\text { Construct }\end{array}$ & $\begin{array}{l}\text { First order } \\
\text { construct }\end{array}$ & Item & $\begin{array}{c}\text { Outer } \\
\text { Loadings }\end{array}$ & AVE & $\begin{array}{l}\text { Composite } \\
\text { Reliability }\end{array}$ & Cronbach Alpha \\
\hline \multirow{2}{*}{$\begin{array}{l}\text { Intention to } \\
\text { Revisit }\end{array}$} & N/A & ITRE1 & N/A & $\mathrm{N} / \mathrm{A}$ & $\mathrm{N} / \mathrm{A}$ & N/A \\
\hline & & ITRE2 & N/A & $\mathrm{N} / \mathrm{A}$ & N/A & $\mathrm{N} / \mathrm{A}$ \\
\hline \multirow{22}{*}{$\begin{array}{l}\text { Service } \\
\text { Quality }\end{array}$} & & - & - & 0.876 & 0.896 & - \\
\hline & Assurance & SQAS1 & 0.772 & 0.805 & 0.875 & 0.876 \\
\hline & & SQAS2 & 0.789 & & & \\
\hline & & SQAS3 & 0.821 & & & \\
\hline & & SQAS4 & 0.799 & & & \\
\hline & Empathy & SQEM1 & 0.879 & 0.875 & 0.889 & 0.834 \\
\hline & & SQEM2 & 0.798 & & & \\
\hline & & SQEM3 & 0.811 & & & \\
\hline & & SQEM4 & 0.832 & & & \\
\hline & & SQEM5 & 0.844 & & & \\
\hline & Reliability & SQRL1 & 0.787 & 0.877 & 0.868 & 0.876 \\
\hline & & SQRL2 & 0.766 & & & \\
\hline & & SQRL3 & 0.791 & & & \\
\hline & & SQRL4 & 0.832 & & & \\
\hline & & SQRL5 & 0.779 & & & \\
\hline & Responsiveness & SQRS1 & 0.843 & 0.865 & 0.865 & 0.854 \\
\hline & & SQRS2 & 0.824 & & & \\
\hline & & SQRS3 & 0.873 & & & \\
\hline & & SQRS4 & 0.829 & & & \\
\hline & Tangibility & SQTG1 & 0.845 & 0.876 & 0.854 & 0.881 \\
\hline & & SQTG2 & 0.834 & & & \\
\hline & & SQTG3 & 0.845 & & & \\
\hline \multirow{4}{*}{$\begin{array}{l}\text { Brand } \\
\text { experience }\end{array}$} & - & - & - & 0.766 & 0.786 & - \\
\hline & Affective & BEA1 & 0.817 & 0.786 & 0.794 & 0.802 \\
\hline & & BEA2 & 0.834 & & & \\
\hline & & BEA3 & 0.863 & & & \\
\hline
\end{tabular}




\begin{tabular}{|c|c|c|c|c|c|c|}
\hline $\begin{array}{l}\text { Second } \\
\text { order } \\
\text { Construct }\end{array}$ & $\begin{array}{l}\text { First order } \\
\text { construct }\end{array}$ & Item & $\begin{array}{l}\text { Outer } \\
\text { Loadings }\end{array}$ & AVE & $\begin{array}{l}\text { Composite } \\
\text { Reliability }\end{array}$ & Cronbach Alpha \\
\hline & \multirow[t]{3}{*}{ Behavioral } & BEB1 & 0.882 & \multirow[t]{3}{*}{0.875} & \multirow[t]{3}{*}{0.822} & \multirow[t]{3}{*}{0.812} \\
\hline & & BEB2 & 0.897 & & & \\
\hline & & BEB3 & 0.846 & & & \\
\hline & \multirow[t]{3}{*}{ Intellectual } & BEI1 & 0.876 & \multirow[t]{3}{*}{0.783} & \multirow[t]{3}{*}{0.795} & \multirow[t]{3}{*}{0.773} \\
\hline & & BEI2 & 0.853 & & & \\
\hline & & BEI3 & 0.874 & & & \\
\hline & \multirow[t]{3}{*}{ Sensory } & BES1 & 0.776 & \multirow[t]{3}{*}{0.787} & \multirow[t]{3}{*}{0.788} & \multirow[t]{3}{*}{0.769} \\
\hline & & BES2 & 0.785 & & & \\
\hline & & BES3 & 0.758 & & & \\
\hline \multirow[t]{6}{*}{ Satisfaction } & \multirow[t]{6}{*}{$\mathrm{N} / \mathrm{A}$} & SAT1 & 0.729 & \multirow[t]{6}{*}{0.765} & \multirow[t]{6}{*}{0.781} & \multirow[t]{6}{*}{0.798} \\
\hline & & SAT2 & 0.799 & & & \\
\hline & & SAT3 & 0.786 & & & \\
\hline & & SAT4 & 0.801 & & & \\
\hline & & SAT5 & 0.791 & & & \\
\hline & & SAT6 & 0.788 & & & \\
\hline
\end{tabular}

Discriminant Validity was surveyed utilizing Farnell and Larcker (1981), and cross loading standard. The result qualities are the relationships between's the latent constructs, which show that there is discriminant legitimacy between every one of the develops. Equally, looking at the loadings over the segments, shows that a indicators's loadings, are constantly higher than the majority of its loadings with different builds. In spite of the fact that Fornell-Larcker and cross-loadings basis are met, a portion of the pointers are somewhat high, which is typical in the assessment of Variance-Based SEM, along these lines, there is discriminant legitimacy between research builds.

Besides, the reworked indicators approach was utilized to manufacture the first-order construct on assigned second-request builds. The progressive segment model, which is a well known methodology in valuing higher order constructs was executed. Table 3 shows the outer t-statistics, outer weights, path coefficient, CR, AVE and also and t-statistic of first-order on assigned second-order construct, demonstrating that Brand Experience, saw as a second order reflective construct, is included Sensory, Affective, Behavioral, and Intellectual parts. Furthermore, Service Quality is contained Tangibility, Reliability, Responsiveness, Assurance, 
and Empathy; and Intention to Revisit is included the Willingness to More Visit.

Table 3. First-order Measurement

\begin{tabular}{|c|c|c|c|c|c|c|c|c|}
\hline $\begin{array}{l}\text { Second order } \\
\text { construct }\end{array}$ & $\begin{array}{l}\text { First order } \\
\text { construct }\end{array}$ & Item & $\begin{array}{c}\text { Outer } \\
\text { Weigh } \\
\text { ts }\end{array}$ & $\begin{array}{c}\text { Outer } \\
\text { T- } \\
\text { Statisti } \\
\text { cs }\end{array}$ & $\begin{array}{c}\text { Path } \\
\text { Coefficie } \\
\text { nt }\end{array}$ & AVE & CR & $\begin{array}{c}\text { T- } \\
\text { statist } \\
\text { ic }\end{array}$ \\
\hline Service & & SQAS & & & & 0.89 & 0.88 & 93.82 \\
\hline \multirow[t]{41}{*}{ Quality } & Assurance & 1 & 0.315 & 41.12 & 0.813 & 7 & 9 & 7 \\
\hline & & SQAS & & & & & & \\
\hline & & 2 & 0.304 & 23.87 & & & & \\
\hline & & SQAS & & & & & & \\
\hline & & 3 & 0.307 & 51.22 & & & & \\
\hline & & SQAS & & & & & & \\
\hline & & 4 & 0.306 & 64.32 & & & & \\
\hline & & SQEM & & & & & & 190.2 \\
\hline & Empathy & 1 & 0.312 & 36.37 & 0.886 & & & 33 \\
\hline & & SQEM & & & & & & \\
\hline & & 2 & 0.301 & 28.91 & & & & \\
\hline & & SQEM & & & & & & \\
\hline & & 3 & 0.309 & 36.12 & & & & \\
\hline & & SQEM & & & & & & \\
\hline & & 4 & 0.311 & 29.11 & & & & \\
\hline & & SQEM & & & & & & \\
\hline & & 5 & 0.319 & 34.19 & & & & \\
\hline & & SQRL & & & & & & 141.4 \\
\hline & Reliability & 1 & 0.298 & 36.23 & 0.823 & & & 56 \\
\hline & & SQRL & & & & & & \\
\hline & & 2 & 0.293 & 41.49 & & & & \\
\hline & & SQRL & & & & & & \\
\hline & & 3 & 0.297 & 23.45 & & & & \\
\hline & & SQRL & & & & & & \\
\hline & & 4 & 0.288 & 63.23 & & & & \\
\hline & & SQRL & & & & & & \\
\hline & & 5 & 0.281 & 46.33 & & & & \\
\hline & Responsiven & SQRS & & & & & & 110.1 \\
\hline & ess & 1 & 0.315 & 48.29 & 0.865 & & & 28 \\
\hline & & SQRS & & & & & & \\
\hline & & 2 & 0.311 & 27.87 & & & & \\
\hline & & SQRS & & & & & & \\
\hline & & 3 & 0.321 & 44.54 & & & & \\
\hline & & SQRS & & & & & & \\
\hline & & 4 & 0.319 & 60.23 & & & & \\
\hline & & SQTG & & & & & & \\
\hline & Tangibility & 1 & 0.275 & 27.54 & 0.817 & & & 35.28 \\
\hline & & SQTG & & & & & & \\
\hline & & 2 & 0.281 & 58.23 & & & & \\
\hline & & SQTG & & & & & & \\
\hline & & 3 & 0.335 & 43.22 & & & & \\
\hline Brand & & & & & & 0.82 & 0.88 & 93.23 \\
\hline experience & Affective & BEA1 & 0.321 & 46.55 & 0.892 & 9 & 4 & 9 \\
\hline
\end{tabular}




\begin{tabular}{|c|c|c|c|c|c|c|c|c|}
\hline $\begin{array}{l}\text { Second order } \\
\text { construct }\end{array}$ & $\begin{array}{l}\text { First order } \\
\text { construct }\end{array}$ & Item & $\begin{array}{c}\text { Outer } \\
\text { Weigh } \\
\text { ts }\end{array}$ & $\begin{array}{l}\text { Outer } \\
\text { T- } \\
\text { Statisti } \\
\text { cs }\end{array}$ & $\begin{array}{c}\text { Path } \\
\text { Coefficie } \\
\text { nt }\end{array}$ & AVE & CR & $\begin{array}{l}\text { T- } \\
\text { statist } \\
\text { ic }\end{array}$ \\
\hline & \multirow{6}{*}{ Behavioral } & BEA2 & 0.327 & 53.87 & & & & \\
\hline & & BEA3 & 0.338 & 28.76 & & & & \\
\hline & & & & & & & & 65.43 \\
\hline & & BEB1 & 0.329 & 18.29 & 0.879 & & & 1 \\
\hline & & BEB2 & 0.331 & 82.23 & & & & \\
\hline & & BEB3 & 0.328 & 74.33 & & & & \\
\hline & \multirow{5}{*}{ Intellectual } & & & & & & & 56.29 \\
\hline & & BEI1 & 0.322 & 45.32 & 0.859 & & & 5 \\
\hline & & BEI2 & 0.332 & 35.69 & & & & \\
\hline & & BEI3 & 0.315 & 14.89 & & & & \\
\hline & & & & & & & & 69.11 \\
\hline & \multirow[t]{3}{*}{ Sensory } & BES1 & 0.325 & 27.12 & 0.883 & & & 5 \\
\hline & & BES2 & 0.312 & 54.86 & & & & \\
\hline & & BES3 & 0.329 & 49.22 & & & & \\
\hline
\end{tabular}

\section{Structural Model}

After estimation items were surveyed, and found as valid and reliable, the subsequent stage is to survey and measure auxiliary model connections. In particular, the primary advances are to survey the basic model in PLS-SEM and to evaluate noteworthiness of the path coefficients. Playing out the PLS-SEM calculation, measures are acquired for the basic model connections (the Path Coefficients) that suggest the estimated connections between the examination builds, the appraisal of the degree of the $\mathrm{R}^{2}$ values as seen in Table 4 .

Table 4: Hypothesis Testing and Structural Relationship

\begin{tabular}{clcccc}
\hline $\begin{array}{c}\text { Hypothes } \\
\text { is }\end{array}$ & \multicolumn{1}{c}{ Path } & $\begin{array}{c}\text { Path } \\
\text { coefficie } \\
\text { nt }\end{array}$ & $\begin{array}{c}\text { Standard } \\
\text { Error }\end{array}$ & T Statistics & $\begin{array}{c}\text { Informatio } \\
\mathbf{n}\end{array}$ \\
\hline H1 & $\begin{array}{l}\text { Service quality } \rightarrow \text { Satisfaction } \\
\text { Service quality } \rightarrow \text { Intention to }\end{array}$ & 0.412 & 0.051 & $8.988^{* * *}$ & Accepted \\
& Hevisit & 0.325 & 0.089 & $3.137^{* * *}$ & Accepted \\
H3 & $\begin{array}{l}\text { Brand Experience } \rightarrow \text { Satisfaction } \\
\text { H3 }\end{array}$ & 0.413 & 0.062 & $8.141^{* * *}$ & Accepted \\
H4 & Brand Experience $\rightarrow$ Intention to & & & & \\
H5 & Revisit & 0.344 & 0.098 & $4.105^{* * *}$ & Accepted \\
& Satisfaction $\rightarrow$ Intention to Revisit & 0.311 & 0.095 & $3.031^{* *}$ & Accepted \\
\hline
\end{tabular}

As seen in Table 4 that hypothesis 1 which proposes service quality positively influences satisfaction with path coefficient $=0.412$ (t-statistic $=8.988)$ and hypothesis 2 which proposes service quality positively influences intention to 
revisit with path coefficient $=0.325(\mathrm{t}$-statistic=3.137) were accepted. In the other side, hypothesis 3 that proposing brand experience positively influences satisfaction with path coefficient $=0.413(\mathrm{t}$-statistic $=8.141)$ and hypothesis 4 that proposing brand experience positively influences intention to revisit with path coefficient $=0.344$ (t-statistic=4.105) were also confirmed. Lastly, it was also accepted for hypothesis 5 that is proposing satisfaction positively influences intention to revisit with path coefficient $=0.311$ (t-statistic=3.031).

\section{Discussion And Conclusions}

Even if various investigations exist on factors that impact the Marine Tourism Attraction, moderately few spotlight on loyalty and Intention to revisit (Rezaei et al., 2017; Peterson, 1995; Amin, 2016; Berezan et al., 2013; Ekinci et al., 2008; Arshad et al., 2016). Distinguishing the impact of Service Quality and Total Experience on post-consuming expectation is essential for managers to expand visitors involvement with regards to the travel industry and pleasantness industry (Rezaei et al., 2017; Manhas and Tukamushaba, 2015; Keshavarz and Jamshidi, 2018; Shi et al., 2014; Teng, 2011; Irfan et al., 2016; Jani and Han, 2014).

As the attainable quality of the travel industry administrations, and the arrangement of value administrations have turned out to be manager concerns, Brand Experience would be improved if the consumer's relationship, with the Marine Tourism Attraction, was seen as significant and if the relationship gave numerous advantages. As needs be, underlining the monetary advantages of the relationship promoting project clarify why some faithfulness projects work, while others come up short. Consumer commitment has demonstrated that there is a positive connection among reliability and gainfulness and traits of accomodation, for example, service quality and brand experience are seen as basic components in evaluating Marine Tourism Attraction quality. Furthermore, supervisors ought to understand that consumers expectation to appreciate more advantages from Marine Tourism Attraction in view of a long haul relationship desire.

The consequences of this research infer that service quality, brand experience and visiors satisfaction are significant in achieving higher traveler spending and intention to revisit. Service quality is an essential angle in separating service that 
prompts upper hands in the service segment. Contributing variables, supporting and comprehension of service quality is significant for service managers all in all and for cordiality industry explicitly, as the consequences of this analysis show that service quality emphatically impact fulfillment and intention to revisit. Hospitality managers, explicitly accomodation eatery managers, ought to know about elements that improve travelers visit behavior and dependability because of the way that the expense of appealing to new customers is multiple times more than that of holding old ones. Then again, accommodation and hospitality directors should upgrade service quality so as to support intention to revisit.

Subsequently, supervisors ought to understand that the substance, solid quality, responsiveness, confirmation and compassion parts of service quality are significant for globally experienced visitors. Also, perceiving the desires and impression of consumers, the estimations of the service quality in each section of the tourism business, would help managers when looked with the test of refining service quality. To improve the substantial quality part of service quality, managers should put an accentuation on good looking accomodation or even café hardware, physical offices and well-formed workers who are fashionable and seem slick. To upgrade the good quality part of service, accommodations in marine tourism attraction should stay faithful to their duties, show a true enthusiasm for undertaking travelers' issues, play out the correct services, give their services on schedule and keep precise records.

The representatives ought to likewise be obliging and have the information to respond to travelers' inquiries. Besides, the sympathy aspect of compelling help quality would be improved if the accomodation or eatery gave travelers singular consideration and offered working hours that were advantageous to them. Representatives ought to consistently be eager to support travelers and never be too occupied to even consider responding to their solicitations. The responsiveness of accomodation would be improve if the representatives knew precisely when administrations ought to be performed and able to gave benefits quickly. Moreover, affirmation would be upgrades if the conduct of representatives propelled trust in explorers and made them have a sense of security when finishing exchanges with 
the accomodation. In conclusion, the staff should give travelers individual consideration and try to comprehend the travelers' particular needs, which thus shows the travelers that the wellbeing is on the most fundamental level.

Executives should improve the tangible part of their image with the goal that it leaves a solid impact on the travelers' visual sense. One of the difficulties confronting the tourism business is ensuring successful promoting rehearses regarding building up a reasonable brand message for tourism attractions; accordingly, there should be more noteworthy consideration by the both scholars and industry experts the same. Affective part of the brand experience would be improved if the accomodation or eatery reflected the emotions and estimations of their visitors. Moreover, as brand experience was found as a second order construct including tangible, full of feeling, behavior and logical, supervisors ought to underline these measurements. Travelers ought to likewise encounter resilient feelings and the hotel or café ought to be seen as an enthusiastic brand.

Moreover, the visitors ought to see the accomodation or eatery as fascinating in a tactile way and the hotel or café should engage their general detects. In order to improve the interactive part of the brand experiences, visitors ought to take part in physical activities and practices, bringing about genuine experiences, which suggest an action-oriented brand. Besides, the logical element of brand experience is satisfied when travelers experience psychological commitment and their interest and critical thinking is animated, while experiencing the hotel. At last, accomodation service managers should concentrate on experience based methodologies as the travel and pleasantness industry are at the milking edge of the experience-based contemporary service segment.

\section{Limitation And Future Research Avenue}

Ultimately, this research utilized a cross sectional information collecting approach. Future analysts ought to maybe get the information utilizing a more complex methodology. Similar with the other experimental research, this exploration had a few constraints which recommend another attempt for further examination. Future research ought to expand the hypothetical research model of this research to other related territories, for example, extravagance the travel 
industry and resort and accomodation support. Initially, this research is limited to the accommodation and tourism industry. Furthermore, this research explores the global travelers in Indonesia. Further research, ought to be embraced to sum up the discoveries of this research in some other regions.

\section{ACKNOWLEDGEMENT}

The researcher would like to thank the editors and reviewers of the journal for their advice and very detailed feedback in improving the quality of the article. It is a pleasure for the researcher to be given the opportunity to contribute articles in this journal. The researcher also would like to thank the previous researches that mainly referred in this research such as Parasuraman et al., (1988), Peterson (1995), Rezaei et al. (2017), Deng et al. (2013), Keshavarz and Jamshidi (2018) and all other previous researches that stated in the bibliography. Usual disclaimers apply.

\section{BIBLIOGRAPHY}

Adam, D.R., Ofori, K.S., Okoe, A.F. and Boateng, H. (2018), "Effects of structural and bonding-based attachment on brand loyalty", African Journal of Economic and Management Studies, Vol. 9 No. 3, pp. 305-318, available at: https://doi.org/10.1108/AJEMS-10-2017-0252

Aissa, S. B. and Goaied, M. (2016), "Determinants of tourism hotel market efficiency", International Journal of Culture, Tourism and Hospitality Research, Vol. 10 No.2, pp. 173-190.

Amin, M. (2016), "Internet banking service quality and its implication on ecustomer satisfaction and e-customer loyalty", International Journal of Bank Marketing, Vol. 34 No. 3, pp. 280-306.

Arshad, T., Zahra, R. and Draz, U. (2016), "Impact of customer satisfaction on image, trust, loyalty and the customer switching behavior in conventional and Islamic banking: evidence from Pakistan”, American Journal of Business and Society, Vol. 1 No. 3, pp. 154-165.

Berezan, 0., Raab, C., Yoo, M. and Love, C. (2013), "Sustainable hotel practices and nationality: The impact on guest satisfaction and guest intention to return", International Journal of Hospitality Management, Vol. 34, pp. 227 - 
233.

Bilgihan, A., Madanoglu, M. and Ricci, P. (2016), "Service attributes as drivers of behavioral loyalty in casinos: the mediating effect of attitudinal loyalty", Journal of Retailing and Consumer Services, Vol. 31, pp. 14-21.

Brakus, J. J., Schmitt, B. H. and Zarantonello, L. (2009), "Brand experience: what is it? How is it measured? Does it affect loyalty?", Journal of Marketing, Vol. 73 No.3, pp. 52-68.

Chang, K.-C., Chen, M. C. and Hsu, C. L. (2010), "Applying loss aversion to assess the effect of customers' asymmetric responses to service quality on postdining behavioral intentions: An empirical survey in the restaurant sector", International Journal of Hospitality Management, Vol. 29 No. 4, pp. 620-631.

Christopher, M., Payne, A. and Ballantyne, D. (2013), Relationship Marketing, Routledge.

Deng, W., Yeh, M. and Sung, M. (2013), "A customer satisfaction index model for international tourist hotels: Integrating consumption emotions into the American Customer Satisfaction Index", International Journal of Hospitality Management, Vol. 35, pp. 133-140.

Ekinci, Y., Dawes, P. L. and Massey, G. R. (2008), "An extended model of the antecedents and consequences of consumer satisfaction for hospitality services", European Journal of Marketing, Vol. 42 No. 112, pp. 35-68.

Ewur, G.D. and Ali, R.S. (2016), "Retail banking in Ghana: critical factors for success", European Journal of Business and Management, Vol. 8 No. 12, pp. 13-30.

Fazal e Hasan, S., Lings, I., Neale, L. and Mortimer, G. (2014), "The role of customer gratitude in making relationship marketing investments successful", Journal of Retailing and Consumer Services, Vol. 21 No. 5, pp. 788-796.

Ferns, B. H. and Walls, A. (2012), "Enduring travel involvement, destination brand equity, and travelers' visit intentions: A structural model analysis", Journal of Destination Marketing \& Management, Vol. 1 No. 1-2, pp. 27-35.

Fornell, C. and Larcker, D. F. (1981), "Evaluating structural equation models with unobservable variables and measurement error", Journal of Marketing 
Research, pp. 39-50.

George, G., Khayesi, J.N.O. and Haas, M.R.T. (2016), "Bringing Africa in: promising directions for management research", Academy of Management Journal, Vol. 59 No. 2, pp. 377-393.

Hair, J. F., Ringle, C. M. and Sarstedt, M. (2011), "PLS-SEM: INDEED A SILVER BULLET", Journal of Marketing Theory and Practice, Vol. 19 No.2, pp. 139151.

Han, H., Kim, Y. and Kim, E. K. (2011), "Cognitive, affective, conative, and action loyalty: testing the impact of inertia", International Journal of Hospitality Management, Vol. 30 No. 4, pp. 1008-1019.

Hasiri, S.M.A. and Afghanpour, M. (2016), "Investigation of the factors affective on the loyalty of customers in banking industry in the framework of the model of personality characteristics of personnel (case study: Sepah Bank in Mazandaran Province)", Procedia Economics and Finance, Vol. 36, pp. 490501.

Hassanli, N., Gross, M. J. and Brown, G. (2016), "The emergence of home-based accommodations in Iran: A study of self-organization", Tourism Management, Vol. 54, pp. 284-295.

Howat, G. and Assaker, G. (2013), "The hierarchical effects of perceived quality on perceived value, satisfaction, and loyalty: Empirical results from public, outdoor aquatic centres in Australia", Sport Management Review, Vol. 16 No.3, pp. 268-284.

Hsu, C. H., Oh, H. and Assaf, A. G. (2011), "A customer-based brand equity model for upscale hotels", Journal of Travel Research, p. 0047287510394195.

Iglesias, 0., Singh, J. J. and Batista-Foguet, J. M. (2011), "The role of brand experience and affective commitment in determining brand loyalty", Journal of Brand Management, Vol. 18 No.8, pp. 570-582.

Irfan, M., Shamsudin, F.M. and Hadi, N.U. (2016), "How important is customer satisfaction? Quantitative evidence from mobile Telecommunication market”, International Journal of Business and Management, Vol. 11 No. 6, pp. 57-69. 
Jani, D. and Han, H. (2014), "Personality, satisfaction, image, ambience, and loyalty: Testing their relationships in the hotel industry" ,International Journal of Hospitality Management, Vol. 37 No. 0, pp. 11-20.

Jin, N., Goh, B., Huffman, L. and Yuan, J. J. (2015), "Predictors and Outcomes of Perceived Image of Restaurant Innovativeness in Fine-Dining Restaurants", Journal of Hospitality Marketing \& Management, Vol. 24 No. 5, pp. 457-485.

Kandampully, J., Keating, B. W., Kim, B. P., Mattila, A. S. and Solnet, D. (2014), "Service Research in the Hospitality Literature Insights from a Systematic Review", Cornell Hospitality Quarterly, Vol. 55 No. 3, pp. 287-299.

Keller, K. L. (1993), "Conceptualizing, measuring, and managing customer-based brand equity", Journal of Marketing, Vol. 57 No. 1, p. 1.

Keshavarz, Y. and Jamshidi, D. (2018), "Service quality evaluation and the mediating role of perceived value and customer satisfaction in customer loyalty”, International Tourism of Tourism Cities, Vol. 4 No. 2, pp. 220-244.

Khodadadi, M. (2016), "Return to glory? Prospects of Iran's hospitality sector postnuclear deal", Tourism Management Perspectives, Vol. 19, pp. 16-18.

Lam, C., Ho, G. K., Law, R., Okumus, F. and Okumus, F. (2015), "How can Asian hotel companies remain internationally competitive?", International Journal of Contemporary Hospitality Management, Vol. 27 No. 5.

Lee, C.-F. (2015), "Tourist satisfaction with factory tour experience", International Journal of Culture, Tourism and Hospitality Research, Vol. 9 No.3, pp. 261 277.

Lee, J.-S., Back, K.-J., Chan, E. S., Okumus, F. and Okumus, F. (2015), "Quality of work life and job satisfaction among frontline hotel employees: a selfdetermination and need satisfaction theory approach", International Journal of Contemporary Hospitality Management, Vol. 27 No.5.

Lee, S. and Kim, D.-Y. (2018), “The effect of hedonic and utilitarian value on satisfaction and loyalty of Airbnb users", International Journal of Contemporary Hospitality Management, Vol. 30 No. 3, pp. 1332-1351.

Lewis, E. F., Hardy, M. and Snaith, B. (2013), "An analysis of survey reporting in the imaging professions: Is the issue of non-response bias being adequately 
addressed?", Radiography, Vol. 19 No. 3, pp. 240-245.

Magasi, C. (2016), "Customer relationship marketing and its Influence on customer retention: a case of commercial banking industry in Tanzania", Journal of Emerging Issues in Economics Finance and Banking, Vol. 5 No. 1, pp. 17561775.

Manhas, P. S. and Tukamushaba, E. K. (2015), "Understanding service experience and its impact on brand image in hospitality sector", International Journal of Hospitality Management, Vol. 45, pp. 77-87.

Martinez, P. and Rodriguez del Bosque, I. (2013), "CSR and customer loyalty: The roles of trust, customer identification with the company and satisfaction", International Journal of Hospitality Management, Vol. 35 No. 0, pp. 89-99.

Mohseni, S., Jayashree, S., Rezaei, S., Kasim, A. and Okumus, F. (2016), "Attracting tourists to travel companies' websites: The structural relationship between website brand, personal value, shopping experience, perceived risk and purchase intention", Current Issues in Tourism.

Nam, J., Ekinci, Y. and Whyatt, G. (2011), "Brand equity, brand loyalty and consumer satisfaction", Annals of Tourism Research, Vol. 38 No.3, pp. 10091030.

Nyadzayo, M.W. and Khajehzadeh, S. (2016), "The antecedents of customer loyalty: a moderated mediation model of customer relationship management quality and brand image", Journal of Retailing and Consumer Services, Vol. 30, pp. 262-270.

O'Mahony, G. B., Sophonsiri, S. and Turner, L. W. (2013), "The impact of the antecedents of relationship development on Thai and Australian resort hotels guests", International Journal of Hospitality Management, Vol. 34, pp. 214226.

Ofori, K.S., Boakye, K. and Narteh, B. (2018), "Factors influencing consumer loyalty towards $3 \mathrm{G}$ mobile data service providers: evidence from Ghana", Total Quality Management \& Business Excellence, Vol. 29 Nos 5-6, pp. 580598.

Ofori, K.S., Boateng, H., Okoe, A.F. and Gvozdanovic, I. (2017), “Examining 
customers' continuance intentions towards internet banking usage", Marketing Intelligence and Planning, Vol. 35 No. 6, pp. 756-773, available at: https://doi.org/10.1108/MIP-11-2016-0214

Oh, H. and Hsu, C. H. C. (2014), "Assessing equivalence of hotel brand equity measures in cross-cultural contexts", International Journal of Hospitality Management, Vol. 36 No. 0, pp. 156-166.

Oliver, R. L. (1997), Satisfaction: A Behavioral Perspective on the Consumer, McGraw Hill.

Oliver, R. L. (1999), "Whence consumer loyalty?", The Journal of Marketing, pp. 33-44.

Parasuraman, A., Zeithaml, V. and Berry, L. (1988), "SERVQUAL: A MultipleItem Scale for Measuring Consumer Perceptions of Service Quality", Journal of Retailing, Vol. 64 No. 1, pp. 12-40.

Peterson, R. A. (1995), "Relationship marketing and the consumer", Journal of the Academy of Marketing Science, Vol. 23 No.4, pp. 278-281.

Quach, T.N., Thaichon, P. and Jebarajakirthy, C. (2016), "Internet service providers' service quality and its effect on customer loyalty of different usage patterns", Journal of Retailing and Consumer Services, Vol. 29, pp. 104-113.

Rahman, M. (2014), "Differentiated brand experience in brand parity through branded branding strategy", Journal of Strategic Marketing, pp. 1-13.

Rezaei, S. (2015), "Segmenting consumer decision-making styles (CDMS) toward marketing practice: A partial least squares (PLS) path modeling approach", Journal of Retailing and Consumer Services, Vol. 22, pp. 1-15.

Sajad Rezaei, Ebrahim Mazaheri, Ramin Azadavar, (2017) "Determinants of experienced tourists' satisfaction and actual spending behavior: a PLS path modelling approach", International Journal of Culture, Tourism and Hospitality Research, Vol. 11 Issue: 2.

Richter, N. F., Cepeda, G., Roldan, J. L. and Ringle, C. M. (2015), "European management research using partial least squares structural equation modeling (PLS-SEM)", European Management Journal, Vol. 33 No. 1, pp. 1-3.

Ronkko, M. and Evermann, J. (2013), "A Critical Examination of Common Beliefs 
About Partial Least Squares Path Modeling", Organizational Research Methods, Vol. 16 No. 3, pp. 425-448.

Saleem, M.A., Zahra, S. and Yaseen, A. (2017), "Impact of service quality and trust on repurchase intentions - the case of Pakistan airline industry", Asia Pacific Journal of Marketing and Logistics, Vol. 29 No. 5, pp. 1136-1159.

Shi, Y., Prentice, C. and He, W. (2014), "Linking service quality, customer satisfaction and loyalty in casinos, does membership matter?", International Journal of Hospitality Management, Vol. 40 No. 0, pp. 81-91.

Tanford, S. (2013), "The impact of tier level on attitudinal and behavioral loyalty of hotel reward program members", International Journal of Hospitality Management, Vol. 34, pp. 285-294.

Tang, L. R. (2014), "The application of social psychology theories and concepts in hospitality and tourism studies: A review and research agenda", International Journal of Hospitality Management, Vol. 36, pp. 188-196.

Teng, C. C. (2011), "Commercial hospitality in restaurants and tourist accommodation: Perspectives from international consumer experience in Scotland", International Journal of Hospitality Management, Vol. 30 No. 4, pp. 866-874.

Theodorakis, N. D., Alexandris, K., Tsigilis, N. and Karvounis, S. (2013), "Predicting spectators' behavioural intentions in professional football: The role of satisfaction and service quality", Sport Management Review, Vol. 16 No. 1, pp. 85-96. 